\title{
A new affordable housing development and the adjacent housing-market response
}

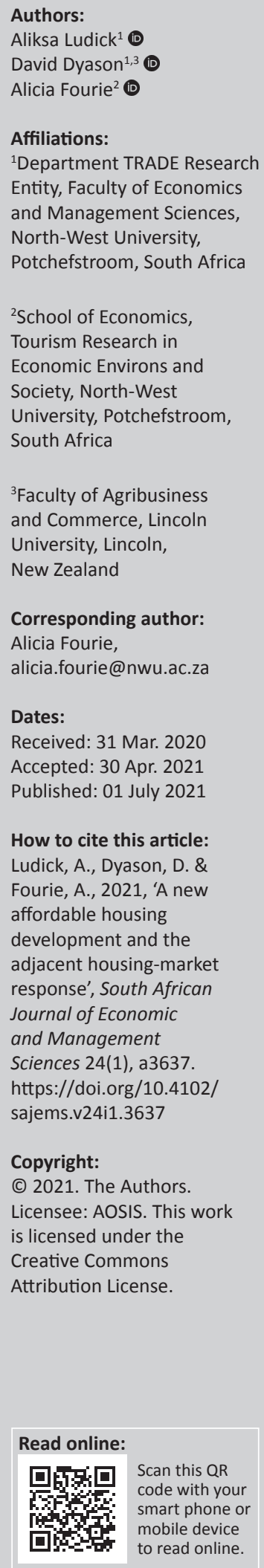

Background: Cities continue to grapple with a rising demand for housing, which affects affordability and the well-being of its citizens. This growth continues to put pressure on the delivery of adequate, affordable housing in well-located areas while the availability of infrastructure and proximity to economic nodes remains a challenge. This has led to increasing infill development of medium-density to high-density affordable housing in greenfield areas located adjacent to higher-income neighbourhoods.

Aim: This study investigates how a new affordable housing development influences the locational and structural values of the adjacent, existing housing market.

Setting: Transactional data of residential sales for two areas in South Africa are used to measure the value change. Both areas are located within an urban setting next to an open, greenfield area that was redeveloped for affordable housing.

Methods: Two case studies are used and analysed with hedonic pricing modelling to identify and measure the value change for the locational and structural characteristics before and after the development of affordable housing.

Results: The results reveal a changing housing market as the locational and structural characteristics change in value, further highlighting the importance of careful planning that preserves the existing market and also supplies affordable housing.

Conclusion: The value of several structural characteristics of properties will change, revealing just how consumer preference responds when affordable housing is introduced in an existing housing market. Distance to an affordable housing project continues to influence the house market value and careful consideration should be made when planning to integrate an affordable housing development in an existing neighbourhood.

Keywords: housing development; affordable housing; hedonic pricing model; residential market; urban; greenfield; impact.

\section{Introduction}

The urban settlement patterns in South Africa have transformed from the post-apartheid era; however, cities continue to grapple with increasing demand for housing within its boundaries. This has led to the promoting of residential density by encouraging integrated mixed-use development (ed. Smith 2003:2), as well as utilising areas that have existing or easy access to horizontal infrastructure. Since 1994, various approaches were undertaken by the government to support the increasing demand for housing and since property was available and more reasonably priced at the edge of urban areas, most affordable housing developments took place at the periphery (Schoonraad 2000:224). This trend has changed recently with an increasing number of affordable housing initiatives being developed in greenfield areas, used as open space and local parks in cities and often located adjacent to existing neighbourhoods (Leshage n.d.; Van der Westhuizen 2020). This is particularly evident in larger cities and metropolitan areas of South Africa where economies of scale in infrastructure provision and better housing opportunities closer to work are targeted.

Housing affordability within the global economy is emerging as a crisis, as housing costs and household income continue to mismatch (Wetzstein 2017). Utilising available open space, within and close to existing neighbourhoods, is in response to increasing development cost at the periphery, but one that could ignore other hidden costs in the economy. As a result, existing neighbourhoods are faced with changing locational characteristics that could shape its housing market. The change in the utility from a local park or green space to affordable housing is expected to have an influence on the house prices of the existing adjacent 
neighbourhood. This study aims to add to this topic by examining the extent of change that an affordable housing development has on the existing market characteristics of an established adjacent neighbourhood. A hedonic pricing model and case studies are used to reveal the locational and structural changes that occur in the housing market within a South African context.

In a recent article, Phakgadi (2019) highlighted that the Constitutional Court ruled for potential new subsidised affordable housing developments to be disapproved if the proposed property could disfigure the area or reduce the value of the adjacent properties. Housing problems and housing developments in South Africa is a contentious issue and, through this research, new learnings related to market-price change would enable more data-driven decision-making when it comes to housing provision.

This article proceeds as follows. First, we discuss the regulating environment related to affordable housing development in South Africa, as well as the extant literature that relates to affordable housing provision and its effect on the surrounding built environment. This is followed by the methodology and results while we end with a conclusion.

\section{Background on affordable housing provision in South Africa}

Recent news media continue to highlight the nature of urbanisation where housing affordability is at the forefront of the debate (Leshage n.d.; Van der Westhuizen 2020). The response to address and provide housing has had a long history in South Africa.

In 2004, the National Department of Housing (NDoH) introduced the Breaking New Ground (BNG) policy in an effort to provide sustainable human settlements and increase the delivery of appropriate housing in the urban core of South African cities. This was done to address the frequent mismatch of housing supply and demand at well-located and in-demand areas. The Integrated Residential Development Programme (IRDP) within the BNG policy was introduced as a result.
The purpose of the IRDP was to foster integrated housing development that caters for a broad spectrum of typologies and affordability levels within the housing market. The programme delivers four different housing typologies, including government subsidy housing, social housing, a finance-linked individual subsidy programme (FLISP) and bonded segment housing. Affordable housing can be termed as a house provided by a social housing government institution or an accredited social housing project, built in a designated restructuring zone for low-to-middle-income earners (Social Housing Policy for South Africa n.d.). For this article, special emphasis will be given to social housing and FLISP initiatives which are henceforth referred to as affordable housing.

The FLISP housing is intended to assist households to access housing, by providing partially subsidised housing that requires a lower deposit on a house. Individuals who can afford personal loans up to R300 000 are eligible for FLISP housing. FLISP housing is greater than $40 \mathrm{~m}^{2}$ and characterised as a detached, semi-detached single or double-storey building (see Figure 1b).

Social housing, illustrated in Figure 1a, is available for individuals earning between R1500 and R15 000 per month and only available for the rental market. The amount of rent paid must not exceed $30 \%$ of the gross income of the tenant. Each unit is between $30 \mathrm{~m}^{2}$ and $45 \mathrm{~m}^{2}$ and comprises one or two bedrooms. The complex is usually characterised by three-storey or four-storey buildings, is accesscontrolled and is owned by an accredited Social Housing Institution for the first 15 years and may either be refinanced or sold thereafter.

Many of the programmes that were implemented by the government to combat the housing backlog, provided housing at a sub-optimal location, often located on the outskirts of urban cities and disconnected from economic networks, hindering sustainable livelihoods and opportunities for residents (COGTA 2016:63). As a result, the Integrated Urban Development Framework (IUDF) was designed to address fragmented settlements, restructure urbanisation and promote integration and inclusion in cities (COGTA 2016:5). The IUDF's focus is on improving the existing built

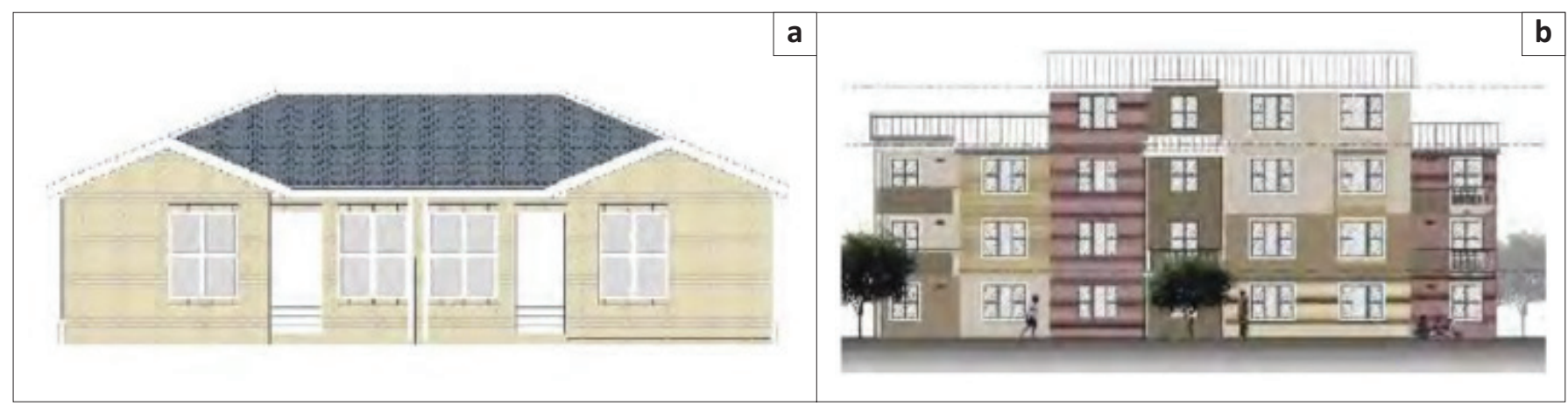

Source: Demacon, 2017, Walmer housing project: Socio-economic impact assessment, South African Council of Shopping Centres (SACSC), Pretoria.

FIGURE 1: Affordable housing. (a) Semi-detached single-story house. (b) Medium-density social housing. 
environment and city footprint, to yield social and economic outcomes by introducing economic nodes and areas for residential housing to stimulate integrated human settlements (COGTA 2016:35). The IUDF provides the policy framework of development planning into which the IRDP feeds to support the housing development component. The outcomes at the heart of the programme are to promote mixed integrated housing developments and address settlement inefficiencies through the integration of individuals from different income groups (National Housing Code 2009:9).

\section{Literature review}

The property price or market price is the actual price of the property on which the consumer and the buyer agree (Pirounakis 2013:384). These values are valued differently by buyers and sellers and also based on the characteristics of the house (Ball, Lizieri \& MacGregor 2012:13).

The location forms part of the value proposition by the market. Tiebout's (1956) invisible foot theory holds that households move between locations that best match their preference, thus the marginal benefit obtained from locational amenities are similar for households living in the same location (Hoyt \& Rosenthal 1997:161). Location imparts a monopoly element of uniqueness or exclusiveness, such as the cost advantage of access to different amenities, or the social connection of growing up in a neighbourhood (Pirounakis 2013:3). Households will choose a neighbourhood based on their sociocultural background or will choose to live where their neighbours are of the same cultural background (Oyebanji 2003:10). This brings one back to the invisible foot theory of the concentration of individuals or households with similar preferences for a feeling of security.

The location factor that is considered when choosing a residential property reflects the individual's preferences and choice of the surrounding neighbourhood. It has an impact on the household's well-being and quality of life (Uchenna 2014:24). Location factors can include, among other things, the proximity to open spaces and parks, the quality of schools or the proximity to economic active areas (Uchenna 2014:3).

Several studies (Du Preez \& Sale 2012; Nelson, Genereux \& Genereux 1992) deal with estimating the complex relationship between property prices and locational characteristics or nonmarket attributes, such as the proximity to waste sites and water pollution. A study conducted on the Nelson Mandela Bay township by Du Preez and Sale (2013) reports that locational characteristics (the distance property is located from the affordable housing development) had a significant negative influence on the property prices in an affluent neighbourhood.

With the migration to large urban areas of people seeking employment, the increasing urban population drives demand for housing which regularly outpaces the supply, especially in the affordable housing segment
(Blaauw et al. 2016; Mafukidze \& Hoosen 2009). This puts pressure on the government and the private sector to allocate sufficient land for housing development to take place. As urbanisation increases, well-located land suitable for affordable housing development becomes more difficult to come by, especially in areas located close to economic nodes that provide employment opportunities (Du Preez \& Sale 2012:1). For those areas where such development has already taken place, there is a growing concern regarding the social and environmental sustainability of these completed housing programmes and the impact upon the adjacent neighbourhoods' property values (Goebel 2007:293). However, Santiago, Galster and Tatian (2001) prove that well-maintained affordable housing programmes can raise property prices of the houses surrounding the development.

Pirounakis (2013:27) describes property price as the value generated from the actual price of the property both the consumer and seller agree upon when making a property transaction deal. This definition assumes both the seller and the buyer have sufficient knowledge of the property and the property market. Residential property is valued as a heterogeneous product, which comprises a bundle of inherent attributes or characteristics that may not be separated from each other since these components refer to the implicit price of the property (Woo 2014:84). The implicit market price of a property can be expressed as a function of attributes, such as the property's structural and locational attributes (Randeniya, Ranasinghe \& Amarawickrama 2017:113).

The characteristics of a house can be divided into structural characteristics, that is, the physical appearance of a property, including the number of bedrooms, number of bathrooms, property age and erf size and its immediate surroundings, as well as locational characteristics, that is, the location unique to a house, proximity to police stations, schools, clinics and retail centres (Goodman 1977:475).

Sirmans, Macpherson and Zietz (2005:4) summarised the top 20 physical characteristics of a house, by examining approximately 125 studies, and divided them into eight different categories: internal and external house features, construction and structure, natural, location and neighbourhood environment, public service environment, occupancy and selling, financial and marketing. Table 1 summarises the top 20 characteristics and their significance.

Property owners have a common belief that affordable housing development located near their homes will automatically decrease their property's value and the neighbourhood's aesthetic qualities. The latter is termed the not-in-my-backyard (NIMBY) theory and based on the idea that affordable housing will be visually unattractive, poorly maintained and managed, which will also, in turn, increase traffic and the level of crime in an area (Habitant \& Humanity 2017). 
TABLE 1: The top 20 characteristics.

\begin{tabular}{|c|c|c|c|c|}
\hline Variable & Appearances & $\begin{array}{c}\text { Times } \\
\text { positive }\end{array}$ & $\begin{array}{c}\text { Times } \\
\text { negative }\end{array}$ & $\begin{array}{l}\text { Times not } \\
\text { significant }\end{array}$ \\
\hline Age & 78 & 7 & 63 & 8 \\
\hline Time on the market & 18 & 1 & 8 & 9 \\
\hline Lot size & 52 & 45 & 0 & 7 \\
\hline Ln lot size & 12 & 9 & 0 & 3 \\
\hline Square feet & 69 & 62 & 4 & 3 \\
\hline Ln square feet & 12 & 12 & 0 & 0 \\
\hline Brick & 13 & 9 & 0 & 4 \\
\hline Fireplace & 57 & 43 & 3 & 11 \\
\hline Basement & 21 & 15 & 1 & 5 \\
\hline Air-conditioning & 37 & 34 & 1 & 2 \\
\hline Garage spaces & 61 & 48 & 0 & 13 \\
\hline Deck & 12 & 10 & 0 & 2 \\
\hline Pool & 31 & 27 & 0 & 4 \\
\hline Bedrooms & 40 & 21 & 9 & 10 \\
\hline Number of stories & 13 & 4 & 7 & 2 \\
\hline Number of bathrooms & 40 & 34 & 1 & 5 \\
\hline Full baths & 37 & 31 & 1 & 5 \\
\hline Number of rooms & 14 & 10 & 1 & 3 \\
\hline Distance & 15 & 5 & 5 & 5 \\
\hline Time trend & 13 & 2 & 3 & 8 \\
\hline
\end{tabular}

Source: Sirmans, S., Macpherson, D. \& Zietz, E., 2005, 'The composition of hedonic pricing models', Journal of Real Estate Literature 13(1), 1-44. https://doi.org/10.1080/ 10835547.2005.12090154

A study compiled by Du Preez and Sale (2012:2) concerning affordable housing in cities and suburbs identified the lack or unavailability of studies that dealt with the impact of a new social housing development on adjacent existing residential property prices. Du Preez and Sale found a case study in the affluent Walmer neighbourhood in South Africa, which is located next to an informal settlement, called Walmer Township. The results of the study indicated that affordable housing development had a statistically significant negative impact on the adjacent Walmer residential property values, more specifically, the average household is willing to pay between R10 092 and R48 459 to move $200 \mathrm{~m}$ further away from the Walmer Township A house located $500 \mathrm{~m}$ away before the development will increase by $49 \%$ value if that same house is located $3200 \mathrm{~m}$ away post-development, indicating that the adjacent neighbourhoods' property price would increase for every metre away from the township (Du Preez \& Sale 2013:464).

The position of this article is to build on the existing literature by identifying if such a development results in a change in market value of the structural and location characteristics of the existing neighbourhood with the development of an affordable housing project. This would enable improved decision-making when identifying open spaces for such developments to encourage appropriate development that aligns with the existing market of the adjacent neighbourhood.

\section{Methodology}

This study follows a combined research approach through a case study analysis and a hedonic pricing to determine the change. A cross-sectional data series of various locational and structural aspects of residential properties is used to investigate the residential market structure pre- and post-development. Pre-development is defined as the period leading up to, but excluding, the construction phase of the affordable housing development. Post-development refers to the period once construction starts, and was chosen since price shifts were observed in the market once construction started, coupled with long construction times on large residential projects. The market responded immediately in both case studies, a suggestion that the NIMBY theory applies earlier than would generally be expected. This is encapsulated by the public's perception of affordable housing developments in close proximity to existing neighbourhoods as detrimental to the area, more specifically, raising the concern about an upsurge in crime due to construction, overcrowding and the general disturbance of peace (Du Preez \& Sale 2013:459).

The two case studies selected are in South Africa: Fleurhof in Randburg and Birch Acres in Kempton Park. These developments were chosen since both case studies are embedded in a previously open-space context where affordable housing typologies have been developed next to an existing neighbourhood, characterised by bonded (middle-to-high-income) housing. Since the residential developments in both case studies have already been completed, they are ideal to analyse and develop policy implications.

The hedonic pricing model is used to value the property's unique attributes and combine these to estimate the price of a property. In doing so, it is assumed that individual households have full information concerning the price and the unique attributes of the residential property (Ham, Maddison \& Elliot 2013:117). The hedonic pricing controls for all the unique attributes affecting the price of the property. The price of the property represents the aggregate price a consumer is willing to pay for the attributes (Chin \& Chau 2003:4).

The hedonic pricing model equation states that the market price of a property is expressed as a function of the structural and locational characteristics (Woo 2014:84). The hedonic pricing model used in this research is as follows:

$$
\begin{aligned}
& (\text { Ppre })=f(S, L)+e \\
& (\text { Ppost })=f(S, L)+e
\end{aligned}
$$

In these equations:

$P=$ A vector of observed property prices

$S=$ A matrix of bedrooms, bathrooms, property age, area size, floor size, garage and pool

$L=$ Distance located from an open space, pre-(greenfield) and post-(build-up).

The residential property data on property prices, structural characteristics and locational characteristics are quantifiable variables. The data includes numerical information such as the actual property price, house attributes and measurable 
distances. The model used to determine the real price of a property is given as:

$$
\begin{aligned}
\text { Real_Price }= & a+b_{0}+b_{1} \text { InYear }+b_{2} \text { InBedrooms }+ \\
& b_{3} \text { InBathrooms }+b_{4} \text { InGarage }+ \\
& b_{5} \text { InErf size }+b_{6} \text { InProperty_age }+ \\
& b_{7} \text { Pool }+Z_{1} \text { InDistance, }
\end{aligned}
$$

The dependent variable in the hedonic pricing model, Real_Price, represents the individual property sales price, $\beta_{1}-\beta_{7}$ represents the independent variables or structural attributes of each property and $\mathrm{Z}_{1}$ represents the distance between the individual property and the open space (pre-development), as well as the proximity between the property and the affordable housing development (post-development). The property prices were adjusted for inflation.

The residential property data was sourced from Property $24^{\circledR}$ and Lightstone Property. Du Preez and Sale (2013) revealed that properties within a $400 \mathrm{~m}$ radius revealed the greatest sensitivity towards affordable housing development. Additionally, a study by Demacon (2017) revealed those properties adjacent to the affordable housing market are referred to as a buffer area and are impacted directly and proportionally more than those located further away. This research study applies these learnings and, as a result, sourced all the transactional data of properties within a 400-m buffer of the development. Google Earth ${ }^{\circledR}$ was used to measure the distance between affordable housing development and adjacent properties. Each house address is measured separately for accuracy in the regression model. The distance located from an open space is recorded as greenfield and distance from the affordable housing is recorded as built-up within the model. To evaluate the effect of the affordable housing development on the location and structural characteristics of the existing neighbourhoods, the model is conducted during two periods. The pre-development phase estimates the value of the characteristics during the period where the site was classified as greenfield. The postdevelopment period is during the period of construction and thereafter. Diagnostic tests confirmed that the models as a whole is significant and no problems were observed.

\section{Ethical considerations}

This article followed all ethical standards for research without direct contact with human or animal subjects.

\section{Results \\ Fleurhof}

Fleurhof originally consisted of mainly low-density, single dwelling freehold residential units. The affordable housing development utilises the greenfield area adjacent to the neighbourhood and developed high-density freestanding and semi-detached housing, providing for an estimated 83000 people (Calgro M3 2016). Freestanding units and apartments were initially sold for R279 000 and R289 000, targeting the affordable housing market (Calgro M3 2016). Freestanding and semi-detached typologies have a size ranging from $40 \mathrm{~m}^{2}$ to $50 \mathrm{~m}^{2}$, have two bedrooms and one bathroom, while freestanding typologies have a size ranging from $60 \mathrm{~m}^{2}$ to $70 \mathrm{~m}^{2}$ and have three bedrooms and one bathroom.

The integrated residential development at Fleurhof started construction in 2013 and continued to be under construction in 2018. The period between 2000 and 2012 is considered the

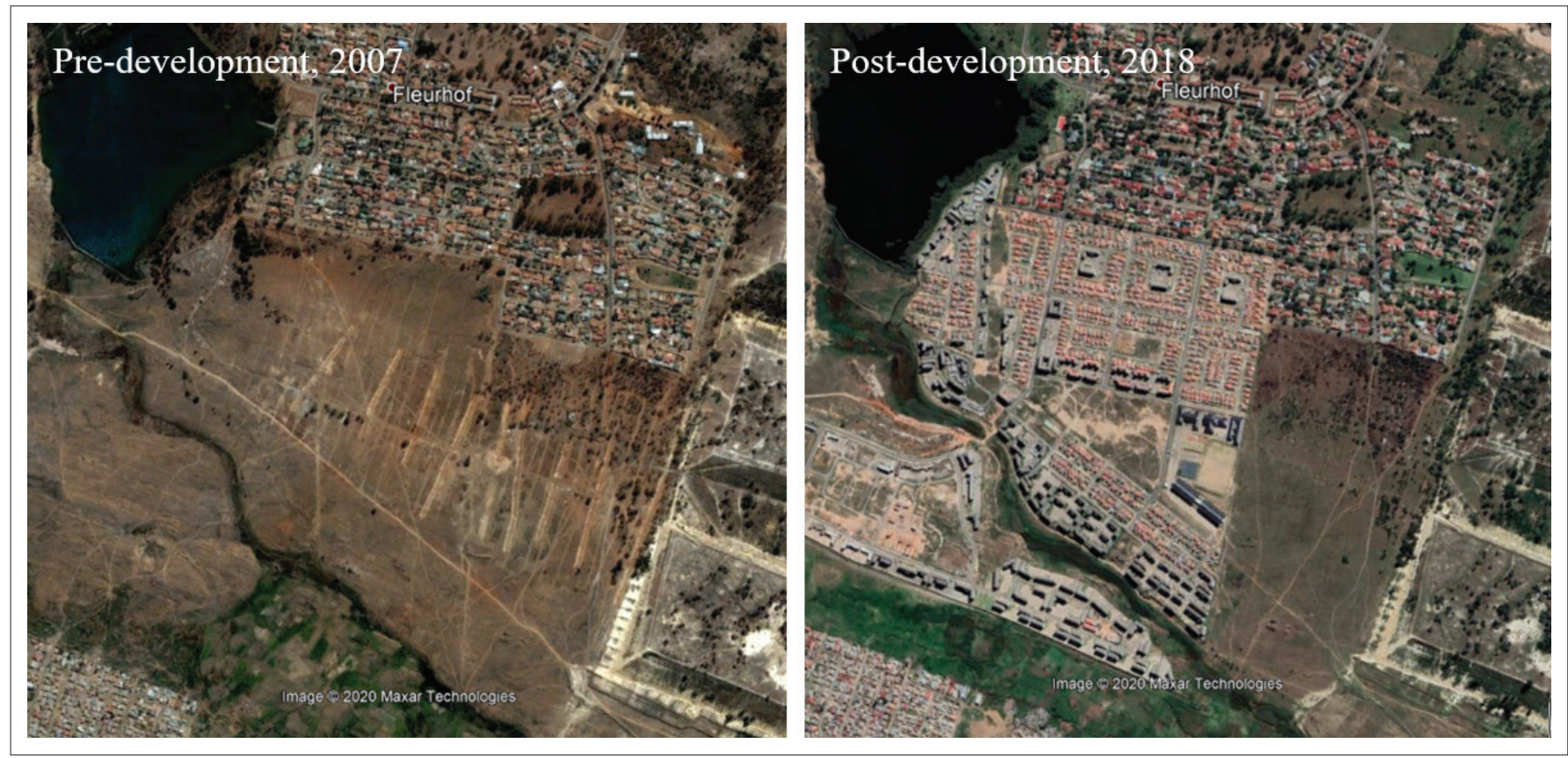

Source: Google Earth, n.d.a, Fleurhof, viewed February 2019, from https://earth.google.com/web/search/Fleurhof/@-26.20395181,27.91395026,1674.50473405a,910.71018023d,35y,172.49628257h, 44.99258995t,0r/data=CnMaSRJDCiUweDFIOTVhMDIIMDQ4MmJmOWI6MHgOYTIIZjhiYZQyMzJiODZjGU_4tqo2MzrAlbxbtFsm6jtAKghGbGV1cmhvZhgCIAEiJgokCaoGI1pm6jnAEbXQnITUGjrAGZrXOBIL RTXAleqhzmHuCzxA.

FIGURE 2: Fleurhof, pre- and post-development. 
pre-development period with 124 transactions while the post-development period is between 2013 and 2018 with 68 transactions (see Figure 2).

A comparison between the average house price before the development with the proposed development price range reveals a significant difference. In 2012, the average property price for Fleurhof was R583 845 (adjusted for inflation) while the suburb had an average of three bedrooms and two bathrooms per house, with an average erf size of 848 $\mathrm{m}^{2}$. This value of the affordable housing project is more than $50 \%$ below the average house price for the neighbourhood prior to its development. This reveals a significant change in the type of residential typology that is

TABLE 2a: Fleurhof model summary.

\begin{tabular}{|c|c|c|c|c|}
\hline \multirow[t]{2}{*}{ Model } & \multicolumn{2}{|c|}{$\begin{array}{l}\text { Unstandardised } \\
\text { coefficients }\end{array}$} & \multirow[t]{2}{*}{$t$} & \multirow[t]{2}{*}{ Significance } \\
\hline & $B$ & $\begin{array}{l}\text { Standard } \\
\text { error }\end{array}$ & & \\
\hline \multicolumn{5}{|c|}{ Fleurhof pre-development } \\
\hline (Constant) & -38445424 & 11871627 & -3.24 & 0.00 \\
\hline Year & 19361 & 5913 & 3.27 & 0.00 \\
\hline Bed & 51395 & 24166 & 2.13 & 0.04 \\
\hline Bath & 19456 & 28982 & 0.67 & 0.50 \\
\hline Garage & 63963 & 23566 & 2.71 & 0.01 \\
\hline Erf & -86 & 106 & -0.81 & 0.42 \\
\hline Pool & -13 & 2826 & -0.004 & 0.996 \\
\hline PROP_AGE & 116804 & 57220 & 2.041 & 0.043 \\
\hline Distance & -23 & 177 & -0.13 & 0.89 \\
\hline \multicolumn{5}{|c|}{ Fleurhof post-development } \\
\hline (Constant) & 35519420 & 32403110 & 1.10 & 0.28 \\
\hline Year & -17025 & 16074 & -1.06 & 0.29 \\
\hline Bed & -53195 & 32718 & -1.63 & 0.11 \\
\hline Bath & 78544 & 33601 & 2.34 & 0.02 \\
\hline Garage & 13625 & 37927 & 0.36 & 0.72 \\
\hline Erf & -134 & 137 & -0.98 & 0.33 \\
\hline Pool & 15273 & 62133 & 0.25 & 0.81 \\
\hline PROP_AGE & 350 & 4115 & 0.09 & 0.93 \\
\hline Distance & -782 & 262 & -2.98 & 0.00 \\
\hline
\end{tabular}

TABLE 2b: Fleurhof model summary.

\begin{tabular}{lccccc}
\hline Model & $\boldsymbol{R}$-squared & $\begin{array}{c}\text { Adjusted } \\
\boldsymbol{R} \text {-squared }\end{array}$ & $\begin{array}{c}\text { Standard } \\
\text { error of the } \\
\text { estimate }\end{array}$ & $\boldsymbol{F}$ & Significance \\
\hline $\begin{array}{l}\text { Model summary } \\
\begin{array}{l}\text { Fleurhof pre- } \\
\text { development }\end{array}\end{array}$ & 0.232 & 0.179 & 216487.019 & 4.357 & $0.000^{*}$ \\
$\begin{array}{l}\text { Fleurhof post- } \\
\text { development }\end{array}$ & 0.281 & 0.184 & 214974.912 & 2.885 & $0.009^{*}$ \\
\hline
\end{tabular}

Significant on $p<0.005$ level. introduced to the market. Keeping this price differential in mind, the results of the hedonic pricing model for both periods are summarised in Table 2.

Comparing the results of the pre-development and postdevelopment model reveals a change in several variables and while these changes will be discussed in more detail in the following section, a couple of relevant changes are emphasised. The prominent result from the model in Table 2 is the change in the coefficient symbol of bedrooms from positive prior to the affordable development, to negative and the increasing value related to distance.

In most instances, a positive coefficient is expected as bedrooms increase with the price of a house as highlighted by Dodds (2010:11). A possible explanation for the contradiction could be due to a changing target market, in which consumers such as young couples prefer smaller houses, which aligns with the affordable housing development. It could also indicate a possible shift in demand for smaller houses, which are more affordable, whereas larger houses with more bedrooms are possibly perceived as more expensive. However, since the $R^{2}$ is low, the cause for this change from positive to negative could be driven from factors outside of the model.

The distance variable continued to be negative in the post-development environment, albeit higher. This suggests that the affordable housing typology introduced to the area did not affect the prices of nearby houses as expected, although priced below the average suburb price. It should be noted that even though the distance is statistically significant, the number of property sales close to the project is low when compared to the total transactional value, with the majority observed farther away from the project.

For this reason, an analysis of the transaction data for homes within $160 \mathrm{~m}$ of the affordable development revealed that there is indeed a positive relationship between distance and property prices in Fleurhof. This result aligns with the existing literature in South Africa that finds similar results. The results hold for both the pre-development and postdevelopment scenarios and are illustrated in Figure 3. In the post-development period, the relationship reveals that house prices close to the affordable housing project remain up to $140 \mathrm{~m}$. The change from $160 \mathrm{~m}$ to $140 \mathrm{~m}$ is as a result of low transactional levels post-development.

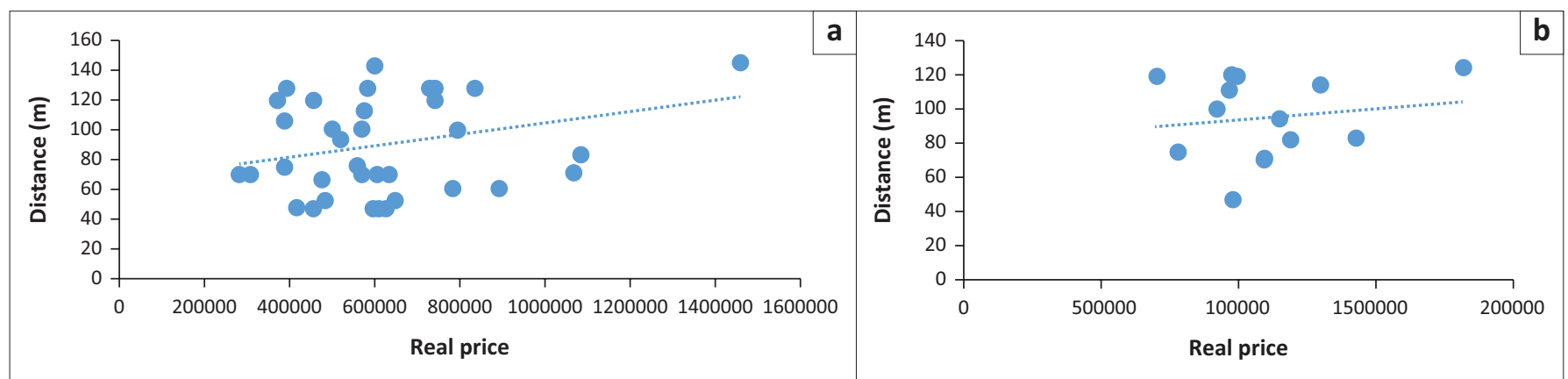

FIGURE 3: Price and distance relationship. (a) Distance up to $160 \mathrm{~m}$, pre-development. (b) Distance up to $140 \mathrm{~m}$, post-development. 


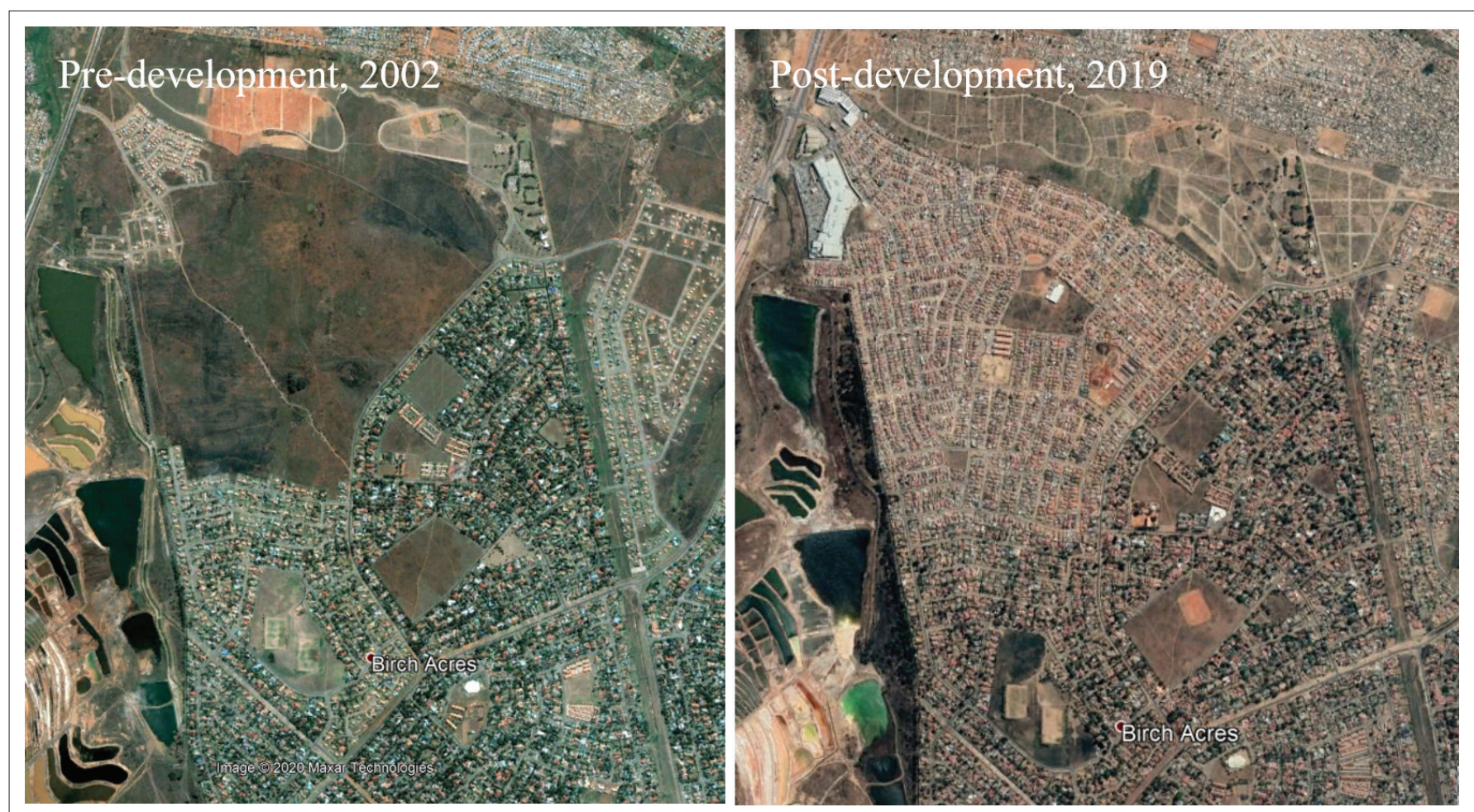

Source: Google Earth, n.d.b, Birch Acers, viewed February 2019, from https://earth.google.com/web/search/Birch+Acres,+Kempton+Park/@-26.05212195,28.20312395,1641.3947101a,10442.49 905347d,35y,Oh,45t,Or/data=CoQBGloSVAolMHgxZTk1NmM5ZTdkZDI4YTJkOjB4MjNhODcONTg2MWUzZDYyNxI3vMIv0Q06wCHiJZOu9DM8QCoZQmlyY2ggQWNyZXMMIEtlbXBOb24gUGFyaxgCIAEiJgokCTZIQDCA 3DRAETRIQDCA3DTAGbjmiUnZejJAIYVqV50PDVXAKAI.

FIGURE 4: Birch Acres, pre- and post-development.

\section{Birch Acres}

Birch Acres located to the north of Kempton Park is a large suburb with a variety of residential typologies. In 2003, prior to the affordable housing development, the average house price for properties located within a 400-m buffer of the greenfield area was R190 857 (adjusted for inflation). The suburb had an average of three bedrooms and two bathrooms per house, while the average erf size was $924 \mathrm{~m}^{2}$.

The development in Birch Acres was aimed at the affordable housing market, particularly the FLISP market and units sold for an average of R74 000, at $61 \%$ lower than the buffer area average house price (Demacon 2017:57). The pre-development period is between 2000 and 2003 and includes 168 transactions, while the post-development period is between 2004 and 2009 with 193 transactions (see Figure 4). Table 3 provides a summary of the pre-development and post-development models.

A comparison of the pre-development results with the postdevelopment results reveals that the bed and bathroom variables have stayed relatively consistent in both periods. The results indicate that properties located near an open space (pre-development) were slightly negatively affected by the proximity to the open field as property prices would increase by R10 per metre or R1000 per $100 \mathrm{~m}$ as distance increased away from the greenfield area. Post development, the value is significantly higher and increased by R35 400 for every $100 \mathrm{~m}$ further away. This result aligns with previous studies of a similar nature in South Africa (Du Preez \& Sale 2013:464) and is an indication that the market
TABLE 3a: Birch Acres model summary.

\begin{tabular}{|c|c|c|c|c|}
\hline \multirow[t]{2}{*}{ Model } & \multicolumn{2}{|c|}{ Unstandardised coefficients } & \multirow[t]{2}{*}{$t$} & \multirow[t]{2}{*}{ Significance } \\
\hline & $B$ & Standard error & & \\
\hline \multicolumn{5}{|c|}{ Birch acres pre-development } \\
\hline (Constant) & -7029546 & 7155639 & -0.982 & 0.327 \\
\hline Year & 11560 & 6788 & 1.703 & 0.091 \\
\hline Bed & 6045 & 6154 & 0.982 & 0.327 \\
\hline Bath & 14253 & 4202 & 3.392 & 0.001 \\
\hline Garage & 103 & 39 & 2.596 & 0.01 \\
\hline Erf & 39303 & 15548 & 2.528 & 0.012 \\
\hline PROP_AGE & 2543 & 896 & 2.836 & 0.005 \\
\hline Pool & 34813 & 3572 & 0.974 & 0.331 \\
\hline Distance & 98 & 43 & 2.259 & 0.025 \\
\hline \multicolumn{5}{|c|}{ Birch acres post-development } \\
\hline (Constant) & -338613788 & 13992142 & -2.42 & 0.016 \\
\hline Year & 16889 & 6974 & 2.421 & 0.016 \\
\hline Bed & 4620 & 21394 & 0.216 & 0.829 \\
\hline Bath & 13953 & 17510 & 0.797 & 0.427 \\
\hline Garage & 11797 & 11155 & 1.058 & 0.292 \\
\hline Erf & 209 & 77 & 2.709 & 0.007 \\
\hline PROP_AGE & 5460 & 1988 & 2.746 & 0.007 \\
\hline Pool & 62428 & 40804 & 1.53 & 0.128 \\
\hline Distance & 354 & 117 & 3.02 & 0.003 \\
\hline
\end{tabular}

TABLE 3b: Birch Acres model summary.

\begin{tabular}{lccccc}
\hline Model & $\boldsymbol{R}$-squared & $\begin{array}{c}\text { Adjusted } \\
\boldsymbol{R} \text {-squared }\end{array}$ & $\begin{array}{c}\text { Standard error } \\
\text { of the estimate }\end{array}$ & $\boldsymbol{F}$ & Significance \\
\hline Model summary & 0.286 & 0.25 & 51801.187 & 7.962 & $0.000^{*}$ \\
$\begin{array}{l}\text { Birch acres pre- } \\
\text { development }\end{array}$ & 0.339 & 0.31 & 144859.33 & 11.773 & $0.000^{*}$ \\
$\begin{array}{l}\text { Birch acres post- } \\
\text { development }\end{array}$ & 0.043 & & & & \\
\hline
\end{tabular}


perceived the affordable housing as intrusive. In the Birch Acres case study, the results support Wheatley (2011) who states that property owners have a common belief that affordable housing development located near their homes will decrease their property's value and the neighbourhood's aesthetic qualities.

\section{Result discussion and implications}

Both case studies confirm that there are changes to how to the locational and structural characteristics of the adjacent existing property market are valued before and during the construction of an affordable housing project. The results reveal that in both case studies, the property age, number of bedrooms, bathrooms and garage spaces is positively affecting the price of the property before the development.

This continued to be positive in Birch Acres, post-development; however, in Fleurhof, a change is observed in bedrooms with a negative coefficient. As explained earlier, this change could be a result of changing consumer preference within the residential market, possibly due to the size and target market related to the housing affordability development.

The erf size changes between the two periods are similar in both case studies. In Fleurhof the negative coefficient increased in the post-development model, suggesting that smaller is preferred by the market and more so after the development. In Birch Acres the value decreased substantially, and although it remained a positive coefficient, the change also suggests that the market moved to smaller erf sizes, aligning with the affordable housing project provisions.

The coefficient for garages remained positive in both case studies and in both models, with Fleurhof showing a lower value associated with an increase in garages, while in Birch Acres more value is associated with increasing garages. A comparison of the census data in 2001 and 2011 (Quantec 2020) for Birch Acres reveals that more households do have access to cars over this period which could explain the additional value associated with garages.

The availability of a pool has increased in value in both case studies after the development. This result is unexpected and could likely reveal an important structural characteristic that supports a property's value, irrespective of changing market conditions.

The locational characteristic of distance reveals a negative coefficient in both periods for Fleurhof but increasing postdevelopment. This suggests that properties closer to the affordable development are valued more than those further away. However, an additional analysis presented earlier reveals that the opposite is revealed for properties near the greenfield site pre- and post-development, with prices increasing as distance from the development site increased up to $140 \mathrm{~m}$ post development. In Birch Acres the coefficient continues to be positive and increase, aligning with the existing literature that locating closer to affordable housing has a negative effect on price. In both case studies the value of the distance coefficient increases in the post-development period.

The hedonic pricing model during both periods reveals the change in the structural and locational characteristics that influence the market price of houses in each case study. Additional to these observed value changes is the price alignment between the existing market and the newly proposed development. In other words, the price differential.

This suggests an analysis of the original price difference between the average property price for the existing neighbourhood versus the average sales price of the affordable housing project. The average sales price in Fleurfof prior to the development was R584 000 (inflation-adjusted), while the affordable housing average price was R280 000 (inflation-adjusted) which translates into a price difference of $52 \%$. At Birch Acres, the average house price was R191 000 (inflation-adjusted) while the average price at the affordable housing development was R70 000 (inflation-adjusted), a $61 \%$ difference. The higher price differential in Birch Areas could further support a positive and increasing distance coefficient evident at Birch Acres, but not at Fleurhof. This points towards a potential price differential cut-off point where a new development between $52 \%$ and $61 \%$ from the average price has a negative effect on the existing house prices of the neighbourhood.

With the increasing demand for land to develop affordable housing development, coupled with the pressure to use infill, greenfield development to limit urban sprawl and utilise existing infrastructure, the results from this study provide important insights to local and regional councils that need to deliberate on relevant planning aspects.

The current market pricing, locational and structural characteristics need to form part of a market analysis that evaluates how an affordable housing development could support, rather than negatively influence the existing adjacent housing market. Ideally, the affordable housing development should reflect comparable characteristics to the surrounding area.

\section{Conclusion}

Delivering adequate and affordable housing for a growing market in well-located areas has resulted in the development of affordable housing projects in open spaces next to established middle-to-high-income neighbourhoods. This is in response to limited available land on the periphery of the urban edge, as well as supplying affordable housing in areas located closer to economic nodes that provide reasonable employment opportunities. There is a growing concern in the marketplace about the effect that such developments have on the existing adjacent residential property prices. In an effort to improve decision-making of the regulatory environment, as well as expand on the knowledge of affordable housing and its effect on the existing market, this study provided insight into that and should be useful for both local and regional planning 
departments when faced with similar applications. The analysis of case studies provides useful support in examining what has worked and what could be done differently.

The results from the hedonic pricing modelling indicated that structural and locational characteristics of the neighbourhood changed in value after the development of affordable housing. The change in value for the structural characteristics was an unexpected result and shows that consumer preferences could alter the ideal typology of the neighbourhood housing market. Distance to an affordable housing project continues to influence the house market value and careful consideration should be made when planning to integrate an affordable housing development into an existing neighbourhood. Ideally, the market price of these units should align with the current market and, to this effect, a price differential analysis could provide useful guidance. Expanding on the market differential analysis is a topic that would require further research.

Lastly, the affordable housing development could consider preserving a part of the greenfield area to represent a green buffer with playgrounds between the existing neighbourhood and affordable housing project. Furthermore, the layout of the housing typology should consider and position the higher-priced affordable units closer to the existing neighbourhood to support the existing market values.

\section{Acknowledgements}

The authors thank FEMS for their financial contribution; NWU for the great opportunity to study and Christien Terblanche for the language editing.

\section{Competing interests}

The authors have declared that no competing interest exists.

\section{Authors' contributions}

All authors contributed equally to this work.

\section{Funding information}

This research received no specific grant from any funding agency in the public, commercial, or not-for-profit sectors.

\section{Data availability}

Data sharing is not applicable to this article as no new data were created or analysed in this study.

\section{Disclaimer}

The views and opinions expressed in this article are those of the authors and do not necessarily reflect the official policy or position of any affiliated agency of the authors.

\section{References}

Ball, M., Lizieri, C. \& MacGregor, B., 2012, The economics of commercial property markets, Routledge, New York.
Blaauw, D., De Beer, J., Viljoen, K. \& Jarbandhan, D.B., 2016, 'Low-cost housing finance and delivery challenges in South Africa', Loyola Journal of Social Sciences 30(2), 169-190.

Calgro M3, 2016, Calgro M3 homes, viewed 12 January 2020, from https://www. calgrom3.com/.

Chin, T. \& Chau, K., 2003, 'A critical review of literature on the hedonic pricing model and its application to the housing market in Penang. The seventh Asian Rea Estate Society Conference', International Journal for Housing Science and its Applications 27(2), 145-165.

Demacon, 2017, Walmer housing project: Socio-economic impact assessment South African Council of Shopping Centres (SACSC), Pretoria.

Department of Cooperative Governance and Traditional Affairs (COGTA), 2016, Vhembe district municipality profile, COGTA, Pretoria.

Dodds, R., 2010, An investigation into the hedonic price analysis of the structural characteristics of residential property in the West Rand, Unpublished Research Report, University of Witwatersrand, Johannesburg.

Du Preez, M. \& Sale, M.C., 2012, 'Determining the impact of a low-cost housing development on nearby property prices using discrete choice analysis', Studies in Economics and Econometrics 36(2), 23-35. https://doi.org/10.1080/10800379.20 12.12097237

Du Preez, M. \& Sale, M.C., 2013, 'The impact of social housing developments on nearby property prices: A Nelson Mandela Bay case study', South African Journal of Economics 81(3), 451-466. https://doi.org/10.1080/10800379.2012.12097237

Goebel, A., 2007, 'Sustainable urban development? Low-cost housing challenges in South Africa', Habitat International 31(3), 291-302. https://doi.org/10.1016/j. habitatint.2007.03.001

Goodman, A.C., 1977, 'A comparison of block group and census tract data in a hedonic housing price model', Land Economics 53(4), 483-487. https://doi. org/10.2307/3145991

Google Earth, n.d.a, Fleurhof, viewed February 2019, from https://earth.google.com/ web/search/Fleurhof/@-26.20395181,27.91395026,1674.50473405a,910.71018 023d,35y,172.49628257h,44.99258995t,Or/data=CnMaSRJDCiUweDFIOTVhMDI MDQ4MmJmOWI6MHgOYTIIZjhiYzQyMzJiODZjGU_4tqo2MzrAlbxbtFsm6jtAKghG bGV1cmhvZhgCIAEiJgokCaoGI1pm6jnAEbXQnIT̄UGjrAGZrXOBILRTXAleqhzm
HuCzxA.

Google Earth, n.d.b, Birch Acers, viewed February 2019, from https://earth.google. com / web/search/Birch+Acres, + Kempton+Park/@26.05212195,28.20312395,1641.3947101a,10442.49905347d,35y,0h,45t,0r/dat $\mathrm{a}=\mathrm{CoQBG}$ IoSVA OIMHgXZTk1NmM5ZTdkZDI4YTJkOjB4M $Q C O Z Q m I$ y 2 g g QWN y ZXMSIEtIbXBOb24gUGFyaxgCIA EiJgokCTZIQDCA3DRAETRIQDCA3DTAGbjmiUnZejJAIYVqV50PDVXAKAI.

Habitat for Humanity, 2017, Affordable for good: Building inclusive communities through homes that last, viewed 22 July 2019, from https://www.habitat.org/ about/advocacy/resources/shelter-report.

Ham, Y.J., Maddison, D.J. \& Elliot, R.J., 2013, 'The valuation of landfill disamenities in Birmingham', Ecological Economies 85(1), 116-129.

Hoyt, W.H. \& Rosenthal, S.S., 1997, 'Household location and Tiebout: Do families sort according to preferences for locational amenities?', Journal of Urban Economics 42(2), 159-178. https://doi.org/10.1006/juec.1996.2019

Leshage, S., n.d., Parks make way for housing development, viewed 12 October 2020 from https://potchefstroomherald.co.za/51568/parks-make-way-housingdevelopment/.

Mafukidze, J.K. \& Hoosen, F., 2009, 'Housing shortages in South Africa: A discussion of the after-effects of community participation in housing provision in Diepkloof', Urban Forum 20(4), 379-396. https://doi.org/10.1007/s12132-009-9068-7

National Housing Code, 2009, Simplified guide to the national housing code: The policy context, Department of Human Settlements, Pretoria.

Nelson, A.C., Genereux, J. \& Genereux, M., 1992, 'Price effects of landfills on house values', Land Economics 68(4), 359-365. https://doi.org/10.2307/3146693

Phakgadi, P., 2019, 'Municipalities should not approve building plans which may devalue surrounding properties. ConCourt rules', viewed 20 February 2019, from https:// www.news24.com/SouthAfrica/News/municipalities-should-not-approve-buildingplanswhich-may-devalue-surrounding-properties-concourt-rules-20190219.

Quantec, 2020, Census 1996, 2001 \& 2011 sub lace and ward level (2011 demarcation) - Separate datasets (Stats SA; Quantec), viewed 14 October 2020, from https:// www.quantec.co.za.

Randeniya, T., Ranasinghe, G. \& Amarawickrama, S., 2017, 'A model to estimate the implicit values of housing attributes by applying the Hedonic pricing method', International Journal of Built Environment and Sustainability 4(2), 113-120. https://doi.org/10.11113/ijbes.v4.n2.182

Santiago, A.M., Galster, G.C. \& Tatian, P., 2001, 'Assessing the property value impacts of the dispersed subsidy housing program in Denver', Journal of Policy Analysis and Management 20(1), 65-88. https://doi.org/10.1002/1520-6688 (200124)20:1\%3C65::AID-PAM1004\%3E3.0.CO;2-U

Schoonraad, M.D., 2000, Cultural and institutional obstacles to compact cities in South Africa, 1st edn., Spon Press, London.

Sirmans, S., Macpherson, D. \& Zietz, E., 2005, 'The composition of hedonic pricing models', Journal of Real Estate Literature 13(1), 1-44. https://doi.org/10.1080/10 835547.2005.12090154

Social Housing Policy for South Africa, n.d., South African Government, Pretoria, viewed 01 February 2020, from https://www.gov.za/sites/default/files/social\%20 housing\%20policy_0.pdf.

Tiebout, C.M., 1956, 'A pure theory of local expenditures', Journal of Political Economy 64(5), 416-424.

Uchenna, A., 2014, Tenant's choice of residential property location in Mankweng Township, Polokwane Local Municipality, Unpublished research report, Master of Administration in Development, University of Limpopo, Limpopo. 
Van der Westhuizen, 2020, Residents worried about large development planned for Mieder Park, viewed 12 October 2020, from https://potchefstroomherald.co. Mieder Park, viewed 12 October 2020, from https://potchefstroomherald.co. park/.

Wetzstein, S., 2017, 'The global urban housing affordability crisis', Urban Studies 54(14), 3159-3177. https://doi.org/10.1177/0042098017711649
Wheatley, D., 2011, Hedonic price method. Economics Network and the Centre for Education in the Built Environment (CEBE), viewed 02 August 2019, from http:// www.cbabuilder.co.uk/Quant5.html.

Woo, A., 2014, 'Sitting of subsidized housing in neighbourhoods: Assessing economic, neighbourhood, and social equity impacts', Doctor of Philosophy Urban and Regional Sciences, Graduate and Professional Studies of Texas A \& M University. 